\title{
"DEVELOPMENT AND VALIDATION OF UV SPECTROPHOTOMETRIC METHODS FOR DETERMINATION OF MEGLUMINE IN BULK"
}

Barge V. U.*, Jadhav P. B., Attarde S. R., Kodre K. V., Yendhe P.R., Patil R. Y.

Pune District Education Associations, Shankarrao Ursal College of Pharmaceutical Science and Research Center, Kharadi, Pune 411 014, India.

E-mail:godse_vijaya@rediffmail.com

\begin{abstract}
-
UV, first, second and third derivative spectrophotometric methods have been developed for the determination of meglumine. The solutions of standard and sample were prepared in distilled water. For the first method i.e. calibration curve UV spectrophotometric method, the quantitative determination of the drug was carried at $254 \mathrm{~nm}$ and the linearity range was found to be $10-60 \mu \mathrm{g} / \mathrm{ml}$. For the first, second, third derivative spectrophotometric methods the drug was determined at $247 \mathrm{~nm}, 216 \mathrm{~nm}, 266 \mathrm{~nm}$ with the linearity range $10-60 \mu \mathrm{g} / \mathrm{ml}$. The calibration graphs constructed at their wavelength of determination were found to be linear for UV and derivative spectrophotometric methods. All the proposed methods have been extensively validated. There was no significant difference between the performance of the proposed methods regarding the mean values and standard deviations.
\end{abstract}

Keywords: UV spectrophotometry; Third derivative spectrophotometry; Meglumine.

\section{Council for Innovative Research}

Peer Review Research Publishing System

Journal: Journal of Advances in Chemistry

Vol. 10, No. 2

editorjaconline@gmail.com

www.cirjac.com 


\section{INTRODUCTION}

Chemically Meglumine is 1-Deoxy-1-(methylamino)-D-glucitol. It acts as contrast media and it was also used as veterinary anti-inflammatory drug and used in treatment of leishmaniasis and also used as contrast media ${ }^{1,4}$.

The literature survey reveals that Meglumine was analysed by HPLC, NMR spectroscopy was used for determination of Meglumine ${ }^{2,3}$. There are no UV and derivative spectrophotometric methods reported for the analysis of meglumine in bulk. Derivative spectrophotometry is an analytical technique of great utility for extracting both qualitative and quantitative information from spectra composed of unresolved bands, and for eliminating the effect of baseline shift and baseline tilts. It consists of calculating and plotting one of the mathematical derivatives of spectral curve. The derivative spectrophotometry is now a reasonable prized standard feature of modern micro - computerized UV spectrophotometry ${ }^{6}$. The aim of this method was to develop and validate UV calibration curve, first, second and third derivative spectrometric methods for determination of meglumine in bulk.

Analysis is an important component in the formulation development of any drug molecule. It becomes essential to develop a simple, sensitive, accurate, precise, reproducible method for the estimation of drug sample. Our main concern is development and validation of UV, first, second and third derivative spectrometric methods for determination of meglumine in bulk.<smiles>CNCC(O)C(O)C(O)CO</smiles>

Fig 1: Structure of Meglumine 4

\section{MATERIAL AND METHODS -}

\subsection{Instruments and Material -}

The instruments used were UV-1800 UV Spectrophotometer SHIMADZU-120 with UV -1800 UV Spectrophotometer ENG 240V Software. Meglumine pure drug and all chemicals and reagents used were of analytical grade.

\subsection{Method-}

\subsubsection{Preparation of Standard Stock Solution}

Accurately weighed $100 \mathrm{mg}$ of drug was transferred to $100 \mathrm{ml}$ volumetric flask. It was dissolved in $25 \mathrm{ml}$ of distilled water and finally volume was made up to the mark with same solvent to obtain solution of concentration $1000 \mu \mathrm{g} / \mathrm{ml}$. Then $1 \mathrm{ml}$ solution from this solution was transferred in $10 \mathrm{ml}$ volumetric flask and volume was made up to the mark by distilled water to obtain $100 \mu \mathrm{g} / \mathrm{ml}^{5}$.

\subsubsection{Determination of $\lambda_{\max }$ for Development of Calibration Curve and Derivative Methods}

From the stock solution, $1 \mathrm{ml}$ of meglumine was transferred to $10 \mathrm{ml}$ volumetric flask and the volume was adjusted to the mark with distilled water to obtain strength $10 \mu \mathrm{g} / \mathrm{ml}$. The solution was scanned in the UV range 200-400 nm.

Determination wavelength for first, second and third derivative The normal UV spectra of $\lambda_{\max } 254 \mathrm{~nm}$ was derivatised into first, second and third order derivative, using UV probe software of instrument. The amplitude of corresponding troughs was measured at $247 \mathrm{~nm}, 216 \mathrm{~nm}, 266 \mathrm{~nm}$.

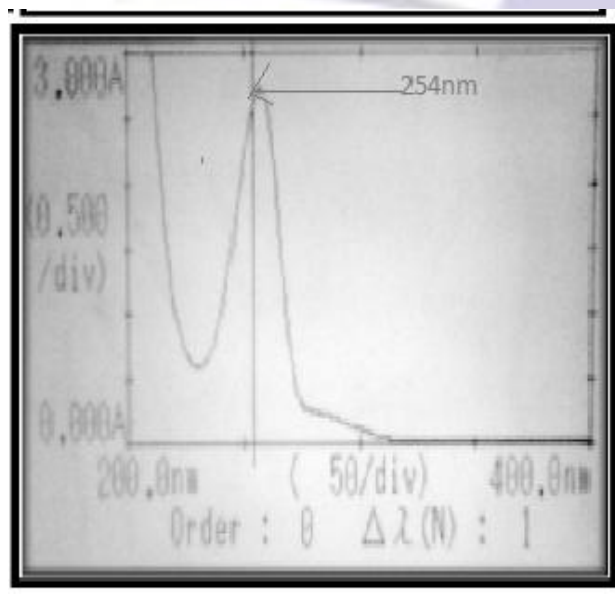

Fig 2: Normal UV spectrum

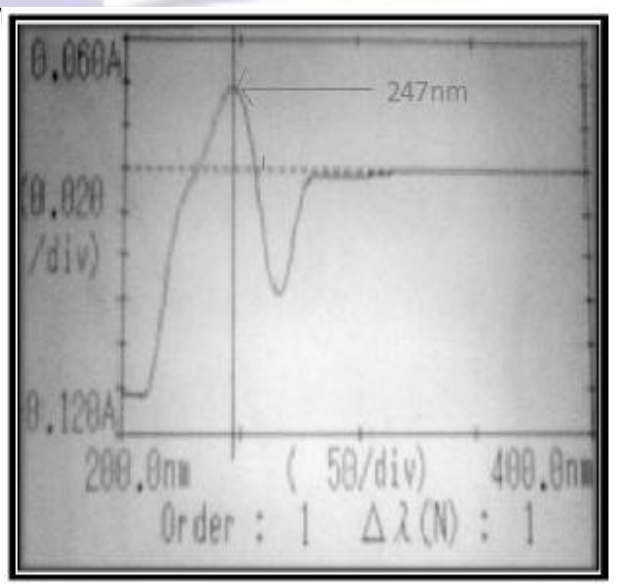

Fig 3: First order derivative spectrum 


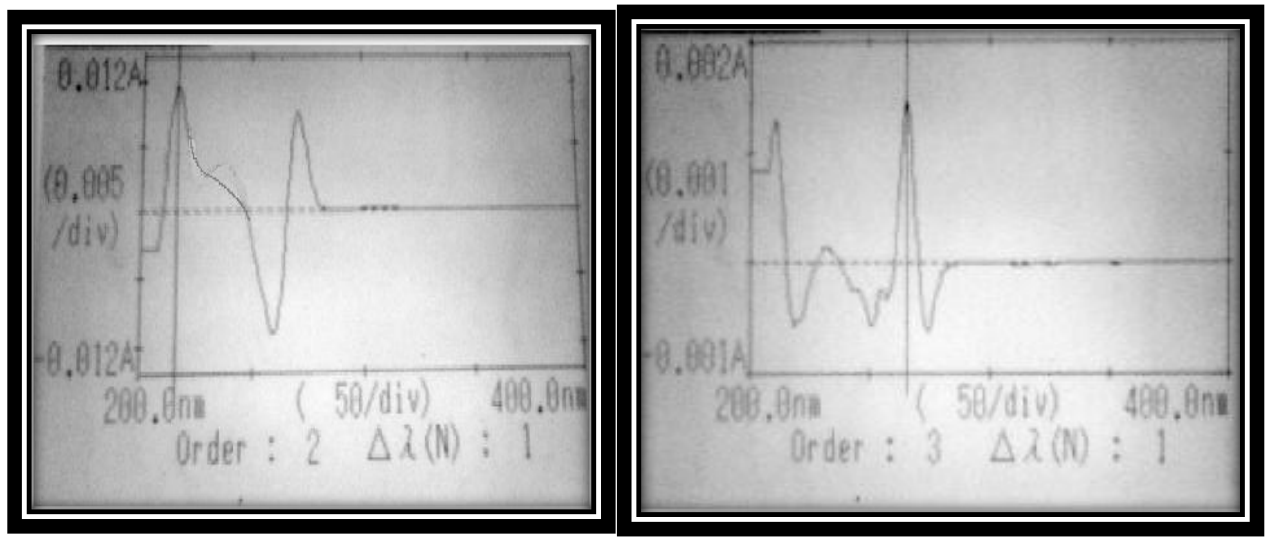

Fig 4: Second order derivative UV spectrum Fig 5: Third order derivative UV spectrum

\section{RESULTS AND DISCUSSION}

Validation of method was done as per ICH guidelines.

\subsection{Accuracy (Recovery Test)}

To study the accuracy of the proposed methods, and to check the interference from excipients used. The mean recoveries were found to be100.02-100.06, 100.00-100.01, 100.00-100.01, and 100.00-100.02\% respectively for UV, first, second, and third derivative spectroscopy ${ }^{5,7}$.("Table 1")

Table 1: Data of accuracy study

\begin{tabular}{|c|c|c|c|c|c|c|}
\hline & $\begin{array}{l}\text { Level of } \\
\% \\
\text { recovery }\end{array}$ & $\begin{array}{c}\text { Preanalysed } \\
\text { conc. } \\
(\mu \mathrm{g} / \mathrm{ml})\end{array}$ & $\begin{array}{l}\text { Spiked } \\
\text { conc. } \\
(\mu \mathrm{g} / \mathrm{ml})\end{array}$ & $\begin{array}{c}\text { Calculated } \\
\text { spiked } \\
\text { conc. }[\mu \mathrm{g} / \mathrm{ml} \\
\pm \text { S.D] } \\
(\mathrm{n}=3)\end{array}$ & $\begin{array}{c}\% \\
\text { R.S.D. }\end{array}$ & $\begin{array}{c}\text { Recovery } \\
(\%)\end{array}$ \\
\hline $\begin{array}{c}\text { UV } \\
\text { Calibration }\end{array}$ & 50 & 30 & 10 & $\begin{array}{l}10.11 \pm \\
0.01429\end{array}$ & 0.12426 & 100.06 \\
\hline & 100 & 30 & 20 & $\begin{array}{c}21.82 \pm \\
0.014299\end{array}$ & 0.06549 & 100.05 \\
\hline & 150 & 30 & 30 & $\begin{array}{c}32.22 \pm \\
0.015821\end{array}$ & 0.0491 & 100.02 \\
\hline $\begin{array}{c}\text { First } \\
\text { derivative }\end{array}$ & 50 & 30 & 10 & $\begin{array}{l}11.09 \pm \\
0.01429\end{array}$ & 0.12886 & 100.00 \\
\hline & 100 & 30 & 20 & $\begin{array}{c}19.82 \pm \\
0.014299\end{array}$ & 0.07249 & 100.01 \\
\hline & 150 & 30 & 30 & $\begin{array}{c}30.22 \pm \\
0.015821\end{array}$ & 0.05235 & 100.00 \\
\hline $\begin{array}{c}\text { Second } \\
\text { derivative }\end{array}$ & 50 & 30 & 10 & $\begin{array}{l}12.90 \pm \\
0.01527\end{array}$ & 0.01284 & 100.00 \\
\hline & 100 & 30 & 20 & $\begin{array}{l}22.95 \pm \\
0.01429\end{array}$ & 0.00575 & 100.01 \\
\hline & 150 & 30 & 30 & $\begin{array}{l}33.15 \pm \\
0.01527\end{array}$ & 0.0461 & 100.00 \\
\hline $\begin{array}{c}\text { Third } \\
\text { derivative }\end{array}$ & 50 & 30 & 10 & $\begin{array}{c}12.05 \pm \\
0.057735\end{array}$ & 0.47913 & 100.00 \\
\hline & 100 & 30 & 20 & $\begin{array}{c}21.90 \pm \\
0.057735\end{array}$ & 0.26363 & 100.02 \\
\hline & 150 & 30 & 30 & $\begin{array}{c}32.19 \pm \\
0.038105\end{array}$ & 0.11838 & 100.001 \\
\hline
\end{tabular}

\subsection{Linearity}

Under the experimental conditions described the graph obtained for UV, first, second and third derivative spectra showed linear relationship. Regression analysis using the method of least-squares was made for the slope. The regression equations of calibration curves were $y=2.2 \times 10^{-3} x+7.1 \times 10^{-3},(r=0.997)$ for the $U V, y=1.2 \times 10^{-4} x+2 \times 10^{-3},(r=0.998)$ for the first, $y=1 \times 10^{-4} x+0.00,(r=0.997)$ for the second and $y=1 \times 10^{-4} x+0.00,(r=0.997)$ for the third derivative 
spectrophotometric methods, respectively. The range was found to be $10-60 \mu \mathrm{g} / \mathrm{ml}$ for UV, first, second and third derivative spectrophotometric methods. The statistical parameters given are the regression equation calculated from the calibration graphs, along with the standard deviations of the slope $\left(\mathrm{S}_{\mathrm{b}}\right)$.

\subsection{Limit of Detection (LOD) and Limit of Quantification (LOQ)}

Limit of detection (LOD) and limit of quantitation (LOQ) were determined by using the formula based on the standard deviation of response and the slope The limit of detection (LOD) and limit of quantification (LOQ) were calculated by using the equations $\mathrm{LOD}=3 \times \sigma / \mathrm{S}$ and $\mathrm{LOQ}=10 \times \sigma / \mathrm{S}$, where $\sigma$ is the standard deviation, $\mathrm{S}$ is the slope ("Table 2")

\subsection{Precision}

To determine the precision of the method, meglumine solutions at a concentration of $40,50,60 \mu \mathrm{g} / \mathrm{ml}$ were analyzed each in triplicate. Solutions for the standard curves were prepared fresh every day. The methods were found to be precise. The \% RSD values for inter day precision studies were found to be $0.0048,0.0024,0.0018$ and 0.00031 for UV, first, second and third derivative spectroscopy. The \% RSD values for intra day precision studies were found to be 0.00768 , $0.00075,0.01355$ and 0.0046 for UV, first, second and third derivative spectroscopy, respectively. The developed methods are accurate, sensitive and precise for determination of meglumine in bulk.

Table 2: Statistical Data for Calibration Curves for Determination of Meglumine

\begin{tabular}{|l|l|l|l|l|}
\hline Parameter & UV & First derivative & Second derivative & $\begin{array}{l}\text { Third } \\
\text { derivative }\end{array}$ \\
\hline Range $(\mu \mathrm{g} / \mathrm{ml})$ & $10-60$ & $10-60$ & $10-60$ & $10-60$ \\
\hline Slop $(\mathrm{b})$ & $\begin{array}{l}2.2 \times 10 \mathrm{x}+7.1 \times \\
10^{-3}\end{array}$ & $1.2 \times 10^{-4} \times+2 \times 10^{-3}$ & $1 \times 10^{-4} \mathrm{x}+0.00$ & $1 \times 10^{-4} \times+0.00$ \\
\hline $\begin{array}{l}\text { Standard deviation } \\
( \pm \text { SD) }\end{array}$ & $3.6 \times 10^{-3}$ & $1.53 \times 10^{-5}$ & $4.65 \times 10^{-5}$ & $4.4 \times 10^{-6}$ \\
\hline $\begin{array}{l}\text { Correlation } \\
\text { coefficient }(r)\end{array}$ & 0.997 & 0.998 & 0.997 & 0.997 \\
\hline LOD & 0.5 & 0.05049 & 1.5 & 0.1 \\
\hline LOQ & 1.6 & 0.153 & 4.6 & 0.44 \\
\hline
\end{tabular}

\section{CONCLUSION}

This is the first study investigating utility of calibration curve, first order, second order and third order of derivative UVspectrophotometric methods for determination of meglumine in bulk. The proposed methods are correct, precise, sensitive and economic and can be used for the routine analysis and quality control of meglumine.

\section{REFERENCES}

1. John, B..; Johan, B. M.2002. Wilson and Gisvold's Textbook, Organic medicinal and pharmaceutical chemistry. $11^{\text {th }}$ edition, Lippincott Williams \& Wilkins, New York, 472-484.

2. Jasprica, I. Mrsic, N. Dragic, T.2011. Determination of meglumine in pharmaceutical formulation using HPLC. PLIVA Croatia Ltd. Research \& development Zagreb crotia. 66(Dec2011), 916-919.

3. Henna, GM. Lau-cam, CA.1996. A Simple method for the identification \& iopamidol \& iothalamate meglumine in pharmaceutical sample based on proton NMR Spectroscopy. Journal of AOAC International and period.79 (Aug 1996), 833-838.

4. European Pharmacopoeia.2010:2055, 2442,2443.

5. Beckett, A.H. Stenlake, J.B.2007. Practical pharmaceutical chemistry. 4th edition, Part-2, CBS Publishers \& Distributors PVT. LTD, India, 275-337.

6. http://en. wikipedia.org/w/index.php?title=Ultraviolet-visible spectroscopy\&oldid=571254022

7. Chatwal.G.R. Anand.S.K.2013. Instrumental Method Of Chemical Analysis. $5^{\text {th }}$ edition, Himalaya publication, New Delhi, 2.149-2.184.

8. HYPAQUE SODIUM (diatrizoate meglumine) Injection, solution, [Amersham Health Inc.] 